\title{
Detection of Functional Nicotinic Receptors Blocked by $\alpha$-Bungarotoxin on PC12 Cells and Dependence of Their Expression on Post-Translational Events
}

\author{
Edward M. Blumenthal, William G. Conroy, Suzanne J. Romano, Paul D. Kassner, and Darwin K. Berg \\ Department of Biology, University of California, San Diego, La Jolla, California 92093
}

A major class of nicotinic receptors in the nervous system is one that binds $\alpha$-bungarotoxin and contains the $\alpha 7$ gene product. PC12 cells, frequently used to study nicotinic receptors, express the $\alpha 7$ gene and have binding sites for the toxin, but previous attempts to elicit currents from the putative receptors have failed. Using whole-cell patch-clamp recording techniques and rapid application of agonist, we find a rapidly desensitizing acetylcholine-induced current in the cells that can be blocked by $\alpha$-bungarotoxin. The current amplitude varies dramatically among three populations of PC12 cells but correlates well with the number of toxin-binding receptors. In contrast, the current shows no correlation with $\alpha 7$ transcript; cells with high levels of $\alpha 7$ mRNA can be negative for toxin binding and yet have other functional nicotinic receptors. Northern blot analysis and reverse transcription-PCR reveal no defects in $\alpha 7$
RNA from the negative cells, and immunoblot analysis demonstrates that they contain full-length $\alpha 7$ protein, although at reduced levels. Affinity purification of toxin-binding receptors from cells expressing them confirms that the receptors contain $\alpha 7$ protein. Transfection experiments demonstrate that PC12 cells lacking native toxin-binding receptors are deficient at producing receptors from $\alpha 7$ gene constructs, although the same cells can produce receptors from other transfected gene constructs. The results indicate that nicotinic receptors that bind $\alpha$-bungarotoxin and contain $\alpha 7$ subunits require additional gene products to facilitate assembly and stabilization of the receptors. PC12 cells offer a model system for identifying those gene products.

Key words: nicotinic; acetylcholine receptors; $\alpha$-bungarotoxin; PC12 cells; $\alpha 7$ gene product; $\alpha 7$ subunits; neuronal
One of the most abundant nicotinic acetylcholine receptors (AChRs) in the vertebrate nervous system is a species that binds $\alpha$-bungarotoxin ( $\alpha \mathrm{Bgt}$ ) and contains $\alpha 7$ subunits (Sargent, 1993; Role and Berg, 1996). The receptor is a cation-selective ligandgated ion channel with a high relative permeability to calcium and rapid desensitization (Couturier et al., 1990; Schoepfer et al., 1990; Zorumski et al., 1992; Alkondon and Albuquerque, 1993; Bertrand et al., 1993; Seguela et al., 1993; Alkondon et al., 1994; Zhang et al., 1994). It is capable of diverse functions, including presynaptic modulation of transmitter release (McGehee et al., 1995; Gray et al., 1996), postsynaptic generation of synaptic currents (Zhang et al., 1996), and regulation of calciumdependent cellular events (Pugh and Berg, 1994; Vijayaraghavan et al., 1995). Recent evidence also links it to a form of schizophrenia (Freedman et al., 1997).

Heterologous expression of the $\alpha 7$ gene in Xenopus oocytes and stably transfected cell lines produces functional $\alpha \mathrm{Bgt}$ sensitive receptors with pharmacological properties similar to

\footnotetext{
Received March 20, 1997; revised May 16, 1997; accepted June 3, 1997.

This work was supported by National Institutes of Health Grants NS12601 and NS35469, the Muscular Dystrophy Association, and the Council for Tobacco Research. E.M.B. is a Muscular Dystrophy Association postdoctoral fellow. P.D.K. is a National Research Service Award postdoctoral fellow. We thank Dr. John Willoughby for RT-PCR cloning of the rat $\alpha 5, \alpha 7$, and $\beta 4$ probes and the $\alpha 7$ fragment encoding the putative cytoplasmic fragment and Dr. Jim Boulter for providing the rat $\alpha 3$ and $\beta 2$ cDNAs. We thank Dr. Jon Lindstrom for providing monoclonal antibodies and Lynn Ogden for excellent technical assistance.

Correspondence should be addressed to Darwin K. Berg, Department of Biology,

0357, University of California, San Diego, 9500 Gilman Drive, La Jolla, CA 92093.

Dr. Blumenthal's present address: Department of Biology, University of Virginia, Charlottesville, VA 22903.

Dr. Romano's present address: Biology Department, Ontogen Corp., Carlsbad, CA 92009.

Copyright (C) 1997 Society for Neuroscience $\quad 0270-6474 / 97 / 170001-11 \$ 05.00 / 0$
}

those of native receptors containing $\alpha 7$ subunits (Couturier et al., 1990; Anand et al., 1993; Gopalakrishnan et al., 1995; Quik et al., 1996). The $\alpha 7$ gene product may assemble into homomeric receptors, although a requirement for additional kinds of subunits has not been excluded. Heteromers of $\alpha 7$ and $\alpha 8$ subunits have been found among chick AChRs but represent a minority of the receptors containing $\alpha 7$ protein (Schoepfer et al., 1990; Keyser et al., 1993; Gotti et al., 1994). Interestingly, when Xenopus oocytes are injected with the $\alpha 7$ gene alone, expression of functional AChRs requires a cyclophilin acting either as a prolyl isomerase or as a chaperone (Helekar et al., 1994). It is not known whether neurons have a similar requirement for cyclophilin.

A continuing challenge to our understanding of receptors containing $\alpha 7$ subunits is that presented by the rat pheochromocytoma cell line PC12 (Greene and Tischler, 1976). PC12 cells express the $\alpha 7$ gene product, along with other nicotinic receptor genes (Boulter et al., 1986, 1990; Rogers et al., 1992; Henderson et al., 1994). Although the cells can assemble receptors that bind $\alpha$ Bgt, no electrophysiological response or ion flux has been attributed to the receptors despite attempts for nearly two decades (Patrick and Stallcup, 1977a,b; Amy and Bennett, 1983; Kemp and Edge, 1987; Daly et al., 1991; Rogers et al., 1991). In contrast, autonomic neurons, which express a similar complement of AChR genes (Listerud et al., 1991; Corriveau and Berg, 1993; Mandelzys et al., 1994), assemble substantial numbers of functional $\alpha$ Bgt-sensitive AChRs that contain $\alpha 7$ subunits and lack the other known AChR gene products present (Vernallis et al., 1993; Zhang et al., 1994). The one indication of functional $\alpha$ Bgt-sensitive AChRs on PC12 cells comes from studies showing that $\alpha$ Bgt blocks the effects of nicotine on neurite outgrowth from the cells (Chan and Quik, 1993). We reexamine here the question 
of whether PC12 cells express AChRs that contain $\alpha 7$ subunits and generate $\alpha$ Bgt-sensitive currents.

\section{MATERIALS AND METHODS}

PC12 cells. PC12 cells were obtained from M. Quik (McGill University) (PC12-A), S. Rogers (University of Utah) (PC12-B), and R. T. Boyd (Ohio State University) (PC12-C). The cell lines were grown at $37^{\circ} \mathrm{C}$ in a humidified incubator under $8 \% \mathrm{CO}_{2}$ and passaged when $70-80 \%$ confluent (trypsin was used to passage the PC12-A cells). The cultures were replaced after 2-3 months of passage by thawing a fresh aliquot of frozen cells. Each strain was maintained in culture medium of the composition used by the source laboratory: PC12-A received DMEM with $4.5 \mathrm{gm} / 1$ glucose, $5 \%$ heat-inactivated fetal bovine serum (Gemini Bio-Products, Calabasas, CA), and $10 \%$ heat-inactivated donor horse serum (Gemini); PC12-B received DMEM with $1 \mathrm{~g} / 1$ glucose, $10 \%$ heat-inactivated fetal bovine serum (Characterized; HyClone, Logan, UT), and 5\% heat-inactivated donor horse serum (Gemini); PC12-C received RPMI 1640 medium with 5\% heat-inactivated fetal bovine serum (Gemini) and 10\% heat-inactivated donor horse serum (Gemini). All media contained $2 \mathrm{~mm}$ glutamine and $50 \mathrm{U} / \mathrm{ml}$ penicillin and streptomycin. In some experiments the culture medium was supplemented with 50-100 ng/ml nerve growth factor (7 S NGF; Promega, Madison, WI) for 3-5 d before assaying the cells.

Electrophysiology. For electrophysiological experiments, cells were plated at low density on $35 \mathrm{~mm}$ tissue culture dishes and used the following day. For PC12-A cells the dishes were first coated with polyL-lysine (Sigma, St. Louis, MO). Currents were recorded using the whole-cell patch-clamp configuration controlled by an Axopatch 200A amplifier (Axon Instruments) as described previously (Hamill et al., 1981; Zhang and Berg, 1995). The extracellular solution contained (in mM) $140 \mathrm{NaCl}, 3 \mathrm{KCl}, 2 \mathrm{MgCl}_{2}, 2 \mathrm{CaCl}_{2}, 10$ glucose, and $10 \mathrm{HEPES}, \mathrm{pH}$ 7.4 (with $\mathrm{NaOH}$ ). The pipette solution contained (in mM) $140 \mathrm{CsCl}, 1$ $\mathrm{MgCl}_{2}, 10$ EGTA, 10 glucose, and 10 HEPES, pH 7.2 (with CsOH). Electrode resistances were $\sim 3 \mathrm{M} \Omega$. Series resistance was always $<6 \mathrm{M} \Omega$ and was $80 \%$ compensated. Cells were clamped at $-60 \mathrm{mV}$, and $500 \mu \mathrm{M}$ $\mathrm{ACh}$ was rapidly applied as follows. Solutions were delivered from a linear array of glass tubing $(370 \mu \mathrm{m}$ inner diameter, $470 \mu \mathrm{m}$ outer diameter; Polymicro Technologies, Phoenix, AZ) mounted on a piezo bimorph element (Morgan-Matroc, Bedford, OH). Solution flow was gravity-fed and controlled by a set of solenoid valves (General Valve, Fairfield, NJ). The valves and the bimorph were all controlled by a Master-8 programmable stimulator (A.M.P.I., Jerusalem, Israel). Using this system, the time of solution exchange at an open pipette was $0.5-3$ msec as measured by the change in junction potential. Data were filtered at $1 \mathrm{kHz}$ and digitized at either 0.7 or $2 \mathrm{kHz}$ with the pClamp software (Axon Instruments). Currents were analyzed using Axograph (Axon Instruments). Maximum activation rates were calculated using the Axograph subroutine and normalized to peak amplitude.

For recordings from $\alpha$ Bgt-treated cells, the toxin (Biotoxins Inc., St. Cloud, FL) was applied at $60 \mathrm{~nm}$ for $1-3 \mathrm{hr}$ at $37^{\circ} \mathrm{C}$, and $18 \mathrm{~nm} \alpha \mathrm{Bgt}$ was also included in the recording solution. For some experiments $1 \mathrm{mg} / \mathrm{ml}$ BSA (Sigma; fraction V, cold alcohol precipitation) was included in the recording solution, because it increased the amplitude of the nicotinic responses that could be elicited from cells after multiple passages in culture. Exposure to BSA had no effect on the $\alpha$ Bgt sensitivity of the response; therefore, results obtained in the presence and absence of BSA were combined in the present analysis. The mechanism of the BSA effect is unknown, although it may be similar to the increased nicotinic response seen in chick ciliary ganglion neurons after acute exposure to BSA (Gurantz et al., 1993).

Monoclonal antibodies. Monoclonal antibodies (mAbs) 318 and 319 were raised against a fusion protein corresponding to the large putative cytoplasmic loop of the chick $\alpha 7$ gene product (Schoepfer et al., 1990); mAb 319 cross-reacts with the rat $\alpha 7$ protein in detergent extracts and on immunoblots, whereas mAb 318 does not (Del Toro et al., 1994) (W. Conroy and D. Berg, unpublished observations). mAb A7-1 has not been described previously. It was raised against a fusion protein corresponding to the large putative cytoplasmic loop of the rat $\alpha 7$ gene product including amino acids 301-439 (numbering as in Seguela et al., 1993). The fusion protein was prepared by generating a PCR fragment encoding the desired region, cloning it into the pRSETB expression vector (Invitrogen, San Diego, CA), and expressing it in bacteria [BL21(DE3)pLysE]. The fusion protein was purified by metal affinity chromatography and used as an immunogen for mAb production as described previously (Vernallis et al., 1993). Hybridomas were screened for antibodies that could immunoprecipitate $\alpha \mathrm{Bgt}$ binding sites labeled with ${ }^{125} \mathrm{I}-\alpha \mathrm{Bgt}$ in PC12 cell extracts. mAb A7-1 was found to be an $\operatorname{IgG} 1$ and was used as diluted ascites fluid for probing immunoblots. mAb 289 recognizes an epitope between residues 330 and 511 on the $\alpha 4$ gene product (Whiting et al., 1991a). The anti-myc mAb 9E10 was obtained commercially (Santa Cruz Biotechnology, Santa Cruz, CA).

Binding assays. The number of $\alpha \mathrm{Bgt}$ binding sites on the surface of PC12 cells was determined as described (Halvorsen and Berg, 1989). PC12 cells were plated on 24 well plates at $10^{5}$ cells $/ 16 \mathrm{~mm}$ well $24-48$ $\mathrm{hr}$ before the assay was conducted. Culture medium was removed and immediately replaced with identical medium that included $10 \mathrm{~nm}{ }^{125} \mathrm{I}$ $\alpha \mathrm{Bgt}$ with and without either $1 \mu \mathrm{M} \alpha \mathrm{Bgt}$ or $250 \mu \mathrm{M}$ nicotine. The cells were incubated for $1 \mathrm{hr}$ at $37^{\circ} \mathrm{C}$ and then were rinsed four times with 2 $\mathrm{ml}$ aliquots of HEPES solution $(137 \mathrm{~mm} \mathrm{NaCl}, 5.4 \mathrm{~mm} \mathrm{KCl}, 0.8 \mathrm{~mm}$ $\mathrm{MgSO}_{4}, 0.9 \mathrm{mM} \mathrm{NaPO}_{4}, 0.4 \mathrm{~mm} \mathrm{~K}_{2} \mathrm{PO}_{4}, 1.8 \mathrm{~mm} \mathrm{CaCl}, 2 \mathrm{mg} / \mathrm{ml} \mathrm{BSA}$, and $10 \mathrm{~mm}$ HEPES, $\mathrm{pH}$ 7.4). Cells were solubilized and scraped in $0.5 \mathrm{ml}$ of $1 \mathrm{~N} \mathrm{NaOH}$; bound radioactivity was quantified by gamma counting. Nonspecific binding determined in the presence of excess unlabeled $\alpha \mathrm{Bgt}$ or nicotine was subtracted to yield specific binding. Results were normalized to total protein, which was assayed by scraping cells in $2 \%$ SDS and $0.1 \mathrm{~N} \mathrm{NaOH}$ and conducting the BCA protein assay (Pierce, Rockford, IL) with BSA as a standard. Determinations were done in triplicate within each experiment.

Both $\alpha$ Bgt and epibatidine binding were determined in cell extracts by scraping PC12 cells into PBS containing $5 \mathrm{~mm}$ EDTA and $5 \mathrm{~mm}$ EGTA, collecting the cells by centrifugation, and freezing at $-80^{\circ} \mathrm{C}$ until needed. Frozen cells were thawed and solubilized in $50 \mathrm{~mm}$ sodium phosphate, $\mathrm{pH} 7.4$, containing $1 \%(\mathrm{v} / \mathrm{v})$ Triton X-100 and the following protease inhibitors: iodoacetamide $(0.4 \mathrm{~mm})$, benzamidine $(5 \mathrm{mM})$, phosphoramidon $(5 \mu \mathrm{g} / \mathrm{ml})$, soybean trypsin inhibitor $(10 \mu \mathrm{g} / \mathrm{ml})$, leupeptin $(10$ $\mu \mathrm{g} / \mathrm{ml})$, pepstatin A $(20 \mu \mathrm{g} / \mathrm{ml})$, EDTA ( $5 \mathrm{~mm})$, EGTA $(5 \mathrm{~mm})$, aprotinin $(2 \mu \mathrm{g} / \mathrm{ml})$, and phenylmethylsulfonyl fluoride $(1 \mathrm{~mm})$. Insoluble material was removed by centrifugation for $15 \mathrm{~min}$ in a microfuge at $4^{\circ} \mathrm{C}$. Detergent extracts were assayed in either of two ways. In one, aliquots (25-50 $\mu \mathrm{l})$ of the three PC12 lines were incubated with $10 \mathrm{nM}{ }^{125} \mathrm{I}-\alpha \mathrm{Bgt}$ or $1-5$ nM ${ }^{3} \mathrm{H}$-epibatidine (DuPont NEN, Boston, MA) for $1 \mathrm{hr}$ at room temperature. The reaction was stopped by the addition of $4 \mathrm{ml}$ of $10 \mathrm{~mm}$ Tris buffer, $\mathrm{pH} 7.5$, containing $0.05 \%$ Triton X-100 (Tris-TX) and immediate filtration through Whatman (Maidstone, UK) GF/B filters treated with $0.5 \%$ polyethyleneimine. The filters were washed twice with Tris-TX and counted in a gamma counter to quantify ${ }^{125} \mathrm{I}-\alpha \mathrm{Bgt}$ or in a scintillation counter to measure ${ }^{3} \mathrm{H}$-epibatidine.

In the second method, detergent extracts were assayed in two-site solid-phase radioimmunoassays (RIAs) as described previously (Conroy and Berg, 1995). Briefly, subunit-specific mAbs were used to immunotether receptors from detergent extracts in microtiter wells, and bound receptors were quantified with radiolabeled probes and either gamma or scintillation counting. AChRs containing $\alpha 7$ protein were retained with the anti- $\alpha 7 \mathrm{mAb} 318$ or 319 and quantified with ${ }^{125} \mathrm{I}-\alpha \mathrm{Bgt}$; AChRs containing the $\alpha 4$ and $\beta 2$ gene products were retained with the anti- $\alpha 4$ mAb 289 and quantified with ${ }^{3} \mathrm{H}$-epibatidine; chimeric receptors containing the $\alpha 7 / 5-\mathrm{HT}_{3}$ receptor construct (see below) were retained with the anti-myc mAb 9E10 (via an incorporated myc epitope) and quantified with ${ }^{125} \mathrm{I}-\alpha$ Bgt. Nonspecific binding in both methods was determined in the presence of $1 \mu \mathrm{M} \alpha \mathrm{Bgt}$ ( $\alpha \mathrm{Bgt}$ assay), $1 \mu \mathrm{M}$ epibatidine (epibatidine assay), or $250 \mu \mathrm{M}$ nicotine (both assays). Results were normalized to total protein as described above. Triplicate determinations were done for each sample.

Receptor purification and immunoblot analysis. PC12-B and -C cells were harvested from $20100 \mathrm{~mm}$ culture plates and solubilized with buffer containing 1\% Triton X-100 as described above. Samples were incubated with $20-50 \mu \mathrm{l} \alpha \mathrm{Bgt}$ coupled to Actigel (Sterogene) for $20 \mathrm{hr}$ at $4^{\circ} \mathrm{C}$. For negative controls, $250 \mu \mathrm{M}$ nicotine was included in the incubation with the $\alpha$ Bgt. After several washes with PBS containing $0.5 \%$ Triton X-100, bound material was eluted with SDS-PAGE sample buffer, and the samples were subjected to SDS-PAGE, electroblotted onto nitrocellulose, and probed with anti- $\alpha 7$ mAbs 319 or A7-1 as described (Corriveau et al., 1995). Bound $\mathrm{mAb}$ was detected with a horseradish peroxidase-coupled antimouse secondary antibody and visualized using enhanced chemiluminescence (Amersham, Arlington Heights, IL) and autoradiography.

Total $\alpha 7$ protein was immunoprecipitated from solubilized cell extracts (1 ml prepared from $30100 \mathrm{~mm}$ plates) of either PC12-B or -C cells using mAb 319 coupled to Actigel $(20 \mu \mathrm{l})$, incubating, and rinsing as above. The bound material was eluted and analyzed on immunoblots probed with $\mathrm{mAb}$ A7-1 as described above.

$R N A$ isolation. Total RNA was isolated from $\mathrm{PC} 12$ cell cultures by acid 
guanidinium thiocyanate-phenol-chloroform extraction (Chomczynski and Sacchi, 1987). RNA was quantified by measuring optical density at $260 \mathrm{~nm}$; RNA integrity was routinely checked by formaldehyde agarose gel electrophoresis.

RNase protection. ${ }^{32} \mathrm{P}$-labeled riboprobes used for $\mathrm{RNase}$ protection experiments were generated by "runoff transcription" from appropriately linearized constructs using methods described previously (Corriveau and Berg, 1993). The $\alpha 3$ probe construct was made by subcloning a fragment encoding amino acids 346-441 from a full-length rat $\alpha 3$ cDNA (Boulter et al., 1986) into pGEM-T (Promega). For the $\beta 2$ probe construct, a 370 base pair fragment was subcloned into pGEM-T from a full-length rat $\beta 2$ cDNA to generate a probe encompassing amino acids 334-457 (Deneris et al., 1988). Portions of the rat $\alpha 5, \alpha 7$, and $\beta 4$ cDNAs were isolated by reverse transcription (RT)-PCR from PC12 total RNA, and the fragments were directly cloned into PGEM-T. The $\beta 4$ probe encodes amino acids 343-442, the $\alpha 5$ probe encodes amino acids 339-405 (Boulter et al., 1990), and the $\alpha 7$ probe encodes amino acids 305-438 (Seguela et al., 1993). The undigested and protected probe sizes, respectively, in base pairs are as follows: $\alpha 3,320$ and 283; $\alpha 5,315$ and 203; $\alpha 7,507$ and 402; $\beta 2,470$ and 370 ; and $\beta 4,372$ and 301 .

RNase protections were performed essentially as described previously (Corriveau and Berg, 1993). For quantification, signals were measured directly from the gels using a Bio-Rad (Richmond, CA) Molecular Imager. Direct comparisons between the subunits were made by taking into account probe-specific activity and the total amount of RNA analyzed. The linearity of the assay was confirmed by varying the amount of total mRNA and quantifying the resulting $\alpha 7$ signal.

Northern blots. PC12 RNA samples were fractionated on $1 \%$ agarose gels containing $7.4 \%$ formaldehyde and transferred to a Hybond $\mathrm{N}$ nylon membrane (Amersham) by capillary blot according to the instructions of the manufacturer. A gel-purified fragment of the $\alpha 7$ cDNA encoding amino acids $305-438$ was labeled to about $10^{9} \mathrm{cpm} / \mu \mathrm{g}$ with $\left[\alpha-{ }^{32} \mathrm{P}\right] \mathrm{dCTP}$ using a random-primed labeling kit (Gibco-BRL, Bethesda, MD). Membranes were prehybridized and hybridized in Rapid-Hyb solution (Amersham) as recommended by the supplier. Nonspecific radioactivity was removed by two $20 \mathrm{~min}$ washes at $65^{\circ} \mathrm{C}$ in $0.1 \times \mathrm{SSC}$ containing $0.1 \%$ SDS. Filters were exposed to Kodak XAR-5 film at $-70^{\circ} \mathrm{C}$ with a DuPont Cronex intensifying screen for 1-2 d.

$R T-P C R$ analysis. First-strand cDNA was synthesized from PC12-B and -C total RNA using a Superscript reverse transcriptase kit (GibcoBRL). PCR was performed using the PCR Optimizer kit (Invitrogen) and the following primers: for fragment a, $5^{\prime}$-aggcatctggetggetctg- $3^{\prime}$ and $5^{\prime}$-tgattctggtccacttaggc-3'; for fragment b, $5^{\prime}$-ctatgagtgctgcaaagagc- $3^{\prime}$ and $5^{\prime}$-tgattctggtccacttaggc- $3^{\prime}$; for fragment c, 5' -ctatgagtgctgcaaagagc- $3^{\prime}$ and $5^{\prime}$-tctgcgcatttcctacttg-3'; and for fragment d, 5'-acctgctctacattggcttc- $3^{\prime}$ and $5^{\prime}$-tctgcgcatttcctacttg-3'. The PCR fragments were separated on $1.1 \%$ agarose gels and visualized by staining with ethidium bromide. Gels were photographed using a Polaroid instant camera.

Chimeric construct. An $\alpha 7 / 5-\mathrm{HT}_{3}$ chimeric receptor gene construct similar to that described previously (Elsele et al., 1993) was made that encoded the N-terminal portion of the chicken AChR $\alpha 7$ subunit extending up to the first putative transmembrane domain (through $\mathrm{Thr}^{230}$ ) and then continued with the remainder of rat $5-\mathrm{HT}_{3}$ receptor subunit (starting with Pro ${ }^{258}$; designating the methionine initiation codon as number 1). A sequential overlapping PCR method was used to join the two cDNAs in frame without the need for matching restriction endonuclease sites (Herlitze and Koenen, 1990). The $\alpha 7$ cDNA was used as a template with oligo-A7NdeIdn (atcttggacatatggaggctgg) and 1u (aataaaggagttctgcgtctcatg). The $5-\mathrm{HT}_{3}$ receptor cDNA was used as a template with oligo-1d (gcagaactcctttattctacgcag) and oligo-5HT3RXhoI (accctcgagggaataatgccaaatg). The resulting overlapping products were gel-purified and used together as a template with the A7NdeIdn and 5HT3RXhoI oligos. The product was subcloned into the pGEM-T vector (Promega), and double-stranded dideoxy sequencing (Sequenase; United States Biochemicals, Cleveland, $\mathrm{OH}$ ) was performed to confirm the sequence. The $S a c$ I-EcoRI fragment of pOPCMVSL $\alpha 7$ myc (constituting a portion of the pOPCMVSL vector and 5' coding region of $\alpha 7$ ) and EcoRI-PfIMI and PfIMI-XhoI fragments of the PCR product were cloned into the $S a c$ I-XhoI fragment of pOPCMVSL $\alpha 7$ myc (the remaining portion of the pOPCMVSL vector).

Transfections. Transient transfection of PC12 cells was accomplished using LipofectAM INE (Gibco-BRL) according to the instructions of the manufacturer and was usually performed in either 60 or $100 \mathrm{~mm}$ culture dishes, and the cells were taken for analysis after 20-48 hr. The transfections used the chimeric $\alpha 7 / 5-\mathrm{HT}_{3}$ receptor gene construct (see above), chicken $\alpha 7$ constructs, or chicken $\alpha 4$ and $\beta 2$ constructs. The chicken $\beta 2$ and $\alpha 4$ constructs were kindly provided by Dr. Paul Whiting (Merck, Sharp, \& Dohme Laboratories, Essex, UK) as expression constructs pCDM8-Ch 23.1 and pCDM8-Ch 26.1 containing the $\beta 2$ and $\alpha 4$ cDNAs, respectively, under cytomegalovirus (CMV) promoters (Whiting et al., 1991b). The chicken $\alpha 7$ constructs were prepared from chicken $\alpha 7$ cDNA under CMV promoters in pOPCMVSL with and without myc epitopes at the $\mathrm{C}$ terminus (additional details to be described elsewhere; $\mathrm{P}$. Kassner and D. Berg, unpublished data).

Materials. $\alpha \mathrm{Bgt}$ was purchased from Biotoxins and radioiodinated to a specific activity of $0.5-0.7 \times 10^{18} \mathrm{cpm} / \mathrm{mol}$ using chloramine T. ${ }^{3} \mathrm{H}$ Epibatidine $(56.5 \mathrm{Ci} / \mathrm{mmol})$ was a gift from DuPont NEN; unlabeled epibatidine was purchased from Research Biochemicals International. mAbs 289, 318, and 319 were supplied by Dr. Jon Lindstrom (University of Pennsylvania, Philadelphia, PA). mAb 319- and $\alpha$ Bgt-Actigel were prepared at 2 and $4-6 \mathrm{mg} / \mathrm{ml}$, respectively, according to the instructions of the manufacturer (Sterogene). The rat $\alpha 5, \alpha 7$, and $\beta 4$ probes and the $\alpha 7$ cytoplasmic fragment were RT-PCR-cloned by Dr. John Willoughby (University of British Columbia, Vancouver, Canada). Dr. Jim Boulter (University of California, Los Angeles, CA) provided the rat $\alpha 3$ and $\beta 2$ cDNAs. All compounds were purchased from Sigma unless otherwise indicated.

\section{RESULTS}

\section{Discovery of $\alpha$ Bgt-sensitive ACh responses}

Whole-cell patch-clamp recording was used to examine AChinduced currents in three populations of PC12 cells obtained from three different laboratories. Agonist was applied by a rapid delivery system to optimize detection of quickly desensitizing currents. ACh at $500 \mu \mathrm{M}$ elicited two kinds of responses that could be distinguished by their apparent kinetics of activation, their rates of desensitization, and their sensitivity to $\alpha \mathrm{Bgt}$. One was a rapidly activating current that quickly desensitized and could be blocked by $\alpha$ Bgt. The other was a more slowly activating current that decayed less quickly and was insensitive to the toxin. The relative proportions of the two kinds of responses differed dramatically among the three PC12 populations tested (Fig. 1, Table 1). PC12-A cells displayed only the rapidly desensitizing response that was completely blocked by $60 \mathrm{nM} \alpha$ Bgt (Fig. $1 A$ ). PC12-B cells, in contrast, had only the slowly desensitizing response that was insensitive to blockade by $\alpha \mathrm{Bgt}$ (Fig. $1 B$ ). PC12-C cells had both kinds of responses (Fig. 1C).

In the case of mixed responses, one method of detecting the rapidly desensitizing toxin-sensitive component is to compare the proportion of the current remaining $30 \mathrm{msec}$ after the peak in the presence and absence of $\alpha \mathrm{Bgt}$. By this criterion PC12-C cells have a toxin-sensitive component, whereas PC12-B cells do not (Table 1). A more sensitive method for revealing even a small amount of the toxin-sensitive response in the presence of a large insensitive response is to take advantage of the observed rapid activation kinetics of the toxin-sensitive component. This was done by calculating the maximum rate of current activation for each cell and normalizing it to the peak amplitude of the response. Comparing these values in the presence and absence of $\alpha \mathrm{Bgt}$ again reveals the rapidly activating $\alpha \mathrm{Bgt}$-sensitive current in PC12-C cells but fails to detect such a component in PC12-B cells (Table 1).

\section{Correlation between $\alpha$ Bgt-sensitive responses and $\alpha$ Bgt binding sites}

The differential effect of $\alpha \mathrm{Bgt}$ on the two classes of ACh-evoked currents suggested that they arose not from different gating modes of a single class of receptor but rather from two pharmacologically distinct receptor subtypes. Accordingly, binding studies were performed to distinguish AChR classes pharmacologically and to correlate them with the currents observed. ${ }^{125} \mathrm{I}-\alpha \mathrm{Bgt}$ was used to quantify $\alpha \mathrm{Bgt}$ binding sites both on the cell surface 
A

\section{$500 \mu \mathrm{M} \mathrm{ACh}$}
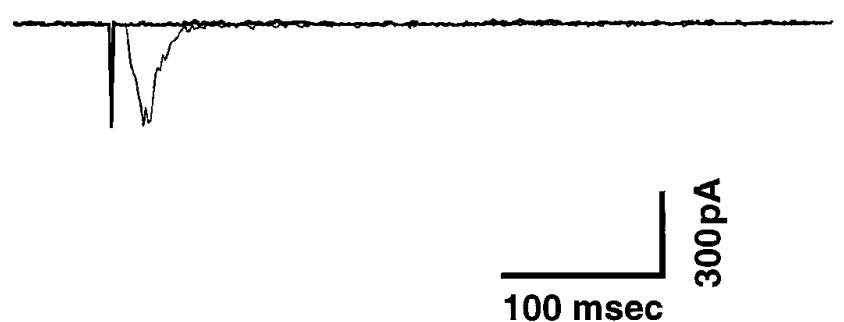

B
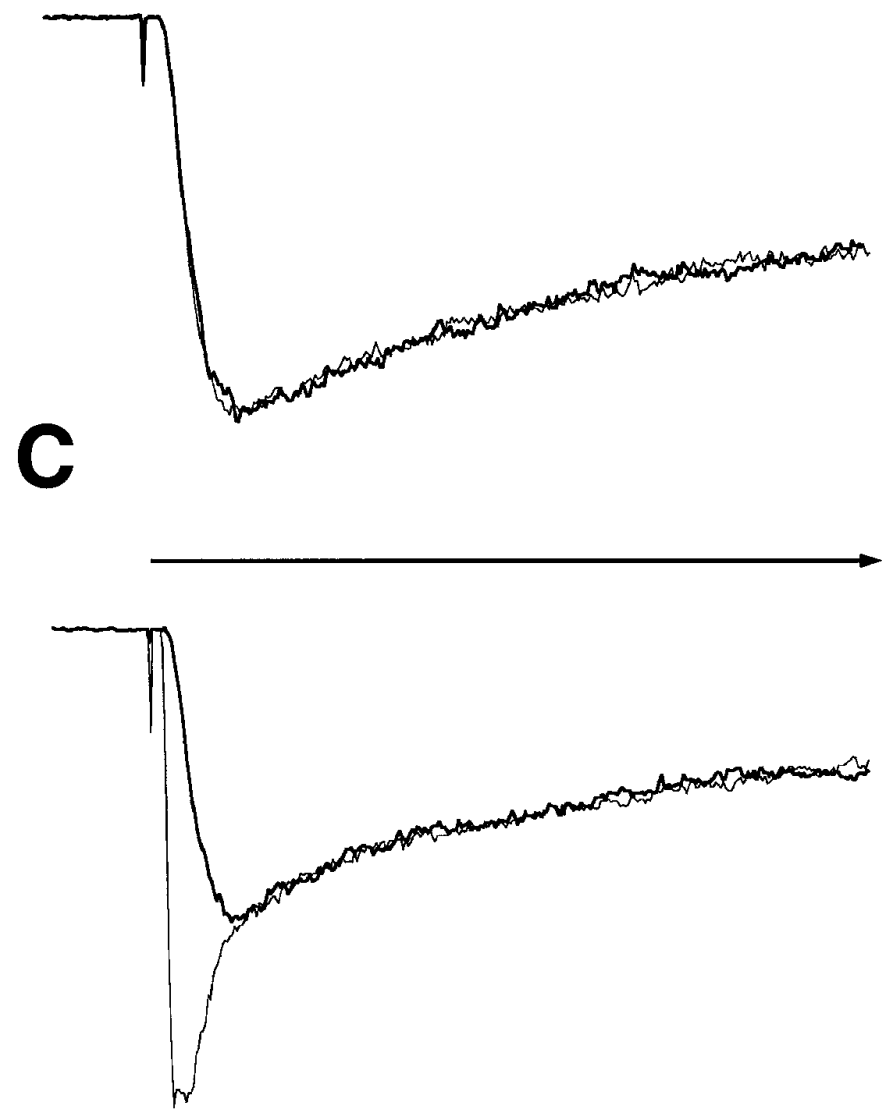

Figure 1. $\alpha$ Bgt blockade of ACh-evoked currents in PC12 cells. Wholecell patch clamp was used to measure currents evoked in PC12-A $(A)$, $\mathrm{PC} 12-\mathrm{B}(B)$, and $\mathrm{PC} 12-\mathrm{C}(C)$ cells by rapid application of $500 \mu \mathrm{M} \mathrm{ACh}$ in the presence and absence of $\alpha$ Bgt. Each panel shows typical responses from a control cell (light trace) and a cell incubated with $60 \mathrm{nM} \alpha \mathrm{Bgt}$ for 1-3 hr (heavy trace) superimposed. PC12-A cells display a small, rapidly activating current that quickly desensitizes and is completely blocked by $\alpha \mathrm{Bgt}$; PC12-B cells show a large, slowly activating current that is completely insensitive to $\alpha \mathrm{Bgt}$; PC12-C cells have both kinds of responses. Holding potential, $-60 \mathrm{mV}$. Calibration bars: horizontal, $100 \mathrm{msec}$ vertical, $300 \mathrm{pA}$. The initiation and duration of ACh application are indicated by the vertical deflection and heavy horizontal arrow, respectively. and in cell extracts. ${ }^{3} \mathrm{H}$-Epibatidine was used to quantify other classes of nicotinic receptors in the extracts. Epibatidine binds with high affinity to many nicotinic receptor subtypes but not those containing rat or chick $\alpha 7$ subunits (Gerzanich et al., 1995) (W. Conroy and D. Berg, unpublished observations). Binding to the cell surface was not attempted with ${ }^{3} \mathrm{H}$-epibatidine, because it seems to cross the cell membrane.

PC12-A cells had a small but significant number of $\alpha \mathrm{Bgt}$ binding sites on the cell surface, whereas PC12-C cells had substantially more (Fig. 2). Both had even greater numbers in cell extracts, implying the existence of intracellular pools of the receptors. PC12-B cells, in contrast, had no detectable sites on the surface and few, if any, in the cell extracts. This pattern of expression could not be explained by the different culture media used for the three populations. Growing the PC12-B cells in culture medium normally used for PC12-C cells did not result in the expression of $\alpha \mathrm{Bgt}$ binding sites. Conversely, PC12-C cells grown in PC12-B medium continued to express $\alpha \mathrm{Bgt}$ binding sites (data not shown).

NGF increases the excitability of PC12 cells (Dichter et al., 1977; Mandel et al., 1988) and can induce long-term expression of a sodium channel gene after even a brief exposure (Toledo-Aral et al., 1995). Because NGF also increases AChR expression in at least some populations of PC12 cells (Dichter et al., 1977; Henderson et al., 1994), its effects on PC12-B cells were tested to determine whether it could induce the appearance of $\alpha$ Bgt-sensitive AChRs. Exposure of the cells to $100 \mathrm{ng} / \mathrm{ml}$ NGF for $4 \mathrm{~d}$ failed to induce any morphological changes or to arrest cell growth and division. Consistent with their nonresponsive phenotype, PC12-B cells in the presence of NGF did not express detectable levels of $\alpha \mathrm{Bgt}$ binding (two experiments gave values of $0.0 \pm 2.0$ and $0.2 \pm 1.0 \mathrm{fmol}$ of $\alpha \mathrm{Bgt}$ binding/mg of protein). NGF treatment stopped cell division in PC12-C cells and caused them to extend neurites, as previously reported for the parent line (Greene and Tischler, 1976), but it had no effect on the expression of $\alpha \mathrm{Bgt}$ binding sites by the cells (two experiments gave $277 \pm 29$ and $371 \pm 12 \mathrm{fmol} / \mathrm{mg}$ protein compared with the mean of about $280 \mathrm{fmol} / \mathrm{mg}$ protein for untreated control cells as shown in Fig. 2).

The distribution of $\alpha \mathrm{Bgt}$ binding sites among the three cell populations correlates with the presence of $\alpha \mathrm{Bgt}$-sensitive currents evoked by $\mathrm{ACh}$ in the cells. The other class of receptors, namely those binding epibatidine, is likely to be responsible for the $\alpha$ Bgt-insensitive currents evoked by ACh. Extracts from all three strains had significant numbers of such receptors, but only the PC12-B and PC12-C cells displayed the slow, toxin-insensitive response (see Discussion).

\section{Lack of correlation between $\alpha$ Bgt-sensitive responses and $\alpha 7$ mRNA}

Because AChRs that bind $\alpha \mathrm{Bgt}$ in autonomic neurons have been shown to contain the $\alpha 7$ gene product (Schoepfer et al., 1990; Vernallis et al., 1993), experiments were performed to compare the levels of $\alpha 7$ transcript among the three PC12 populations. RNase protection assays revealed the presence of $\alpha 7$ mRNA in all three types of PC12 cells (Fig. $3 A$ ). In fact, PC12-B cells, which lack detectable $\alpha \mathrm{Bgt}$ binding sites, had by far the greatest abundance of $\alpha 7$ transcripts (Fig. 3B). PC12-B cells also expressed substantial amounts of the other four AChR gene transcripts tested: $\alpha 3, \alpha 5, \beta 2$, and $\beta 4$. PC12-A and -C cells expressed the same five genes, with the exception of $\beta 4$ in PC12-A. The lack of $\beta 4$ transcripts in PC12-A cells might account for the absence of a 


\begin{tabular}{|c|c|c|c|c|c|c|}
\hline Cell type & $n$ & $\begin{array}{l}\mathrm{C}_{\mathrm{m}} \\
(\mathrm{pF})\end{array}$ & $\begin{array}{l}\text { Current } \\
(\mathrm{pA})\end{array}$ & $\begin{array}{l}\text { Current density } \\
(\mathrm{pA} / \mathrm{pF})\end{array}$ & $\mathrm{I}_{30} / \mathrm{I}_{\text {peak }}$ & $\begin{array}{l}\text { Activation rate } \\
\left(\sec ^{-1}\right)\end{array}$ \\
\hline PC12-A & 148 & $10.9 \pm 0.3$ & $215 \pm 30$ & $19 \pm 2$ & $0.11 \pm 0.01$ & $256 \pm 15$ \\
\hline$+\alpha \mathrm{Bgt}$ & 40 & $11.4 \pm 0.6$ & 0 & 0 & - & - \\
\hline PC12-B & 73 & $11.7 \pm 0.3$ & $1814 \pm 179$ & $154 \pm 14$ & $0.92 \pm 0.01$ & $60 \pm 2$ \\
\hline$+\alpha \mathrm{Bgt}$ & 3 & $11.5 \pm 0.4$ & $2121 \pm 247$ & $192 \pm 23$ & $0.92 \pm 0.01$ & $57 \pm 2$ \\
\hline PC12-C & 117 & $14.6 \pm 0.3$ & $2418 \pm 181$ & $178 \pm 14$ & $0.74 \pm 0.02$ & $120 \pm 5$ \\
\hline$+\alpha \mathrm{Bgt}$ & 5 & $14.6 \pm 0.4$ & $1763 \pm 146^{*}$ & $131 \pm 12^{*}$ & $0.90 \pm 0.01^{* *}$ & $69 \pm 2^{* *}$ \\
\hline
\end{tabular}

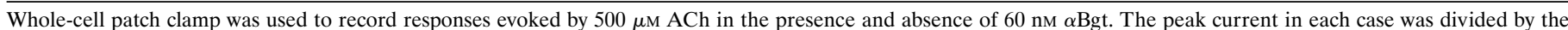

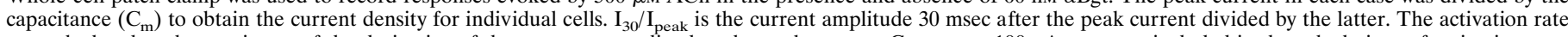

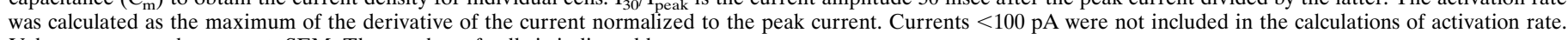
Values represent the mean \pm SEM. The number of cells is indicated by $n$.

* **Significantly different from paired values in the absence of $\alpha \mathrm{Bgt} ;{ }^{*} p \leq 0.02$; * $p \leq 0.001$, Student's $t$ test.

Figure 2. Differences among PC12 populations in their relative levels of AChRs that bind $\alpha$ Bgt and epibatidine. ${ }^{125} \mathrm{I}-\alpha \mathrm{Bgt}$ was used to measure binding sites on intact cells, whereas both ${ }^{125} \mathrm{I}-\alpha \mathrm{Bgt}$ and ${ }^{3} \mathrm{H}$-epibatidine were used to quantify sites in cell extracts. The results were normalized for total protein. Nonspecific binding was determined by adding $1 \mu \mathrm{M} \alpha \mathrm{Bgt}(\alpha \mathrm{Bgt}$ assays), $1 \mu \mathrm{M}$ epibatidine (epibatidine assay), or $250 \mu \mathrm{M}$ nicotine (both assays) to the binding reactions and was subtracted from the values shown. PC12-A and -C cells express significant amounts of $\alpha \mathrm{Bgt}$ binding sites both on the surface (solid bars) and in cell extracts (stippled bars), whereas PC12-B cells have few if any specific $\alpha$ Bgt binding sites. All three populations have significant epibatidine binding (hatched bars). Data represent the mean \pm SEM of triplicate determinations from four to seven independent experiments.

slow $\alpha$ Bgt-insensitive response, which was prominent in PC12-B and $-\mathrm{C}$ cells.

One explanation for the finding that PC12-B cells express $\alpha 7$ mRNA and yet fail to assemble $\alpha$ Bgt-binding AChRs is that the transcripts may be defective. A first test of this was performed by Northern blot analysis. Total RNA was extracted from both PC12-B and PC12-C cells and probed on Northern blots with a random-primed, ${ }^{32} \mathrm{P}$-labeled $\alpha 7$ probe. A single band of about 6.4 $\mathrm{kb}$ was observed in the two samples (Fig. 4). The results indicate that the defect preventing accumulation of $\alpha \mathrm{Bgt}$-sensitive AChRs in PC12-B cells is unlikely to result from a large truncation or deletion in the $\alpha 7$ transcript.

Bovine adrenal chromaffin cells express a truncated splice variant of the $\alpha 7$ transcript that lacks 87 nucleotides corresponding to an exon encoding the M2 domain and adjacent regions (Garcia-Guzman et al., 1995). When co-injected with full-length $\alpha 7$ transcript into Xenopus oocytes, the truncated splice variant inhibits the expression of functional AChRs. A deletion of this size would probably not have been detected in the Northern analysis. Therefore, RT-PCR analysis was performed over the region in question as well as adjacent regions to determine whether such a deletion might account for the inability of PC12-B cells to produce competent $\alpha \mathrm{Bgt}$-binding AChRs. Primers were chosen to amplify fragments corresponding to nucleotide positions 18-1000 (a), 627-1000 (b), 627-1534 (c), and 1148-1534 (d) (Fig. $5 A$; numbering as in Seguela et al., 1993). Only the expected full-length fragment was obtained in each case, and no size differences were detected between PC12-B and -C cells (Fig. 5B). The small 627-1000 fragment includes the M2 region; even a

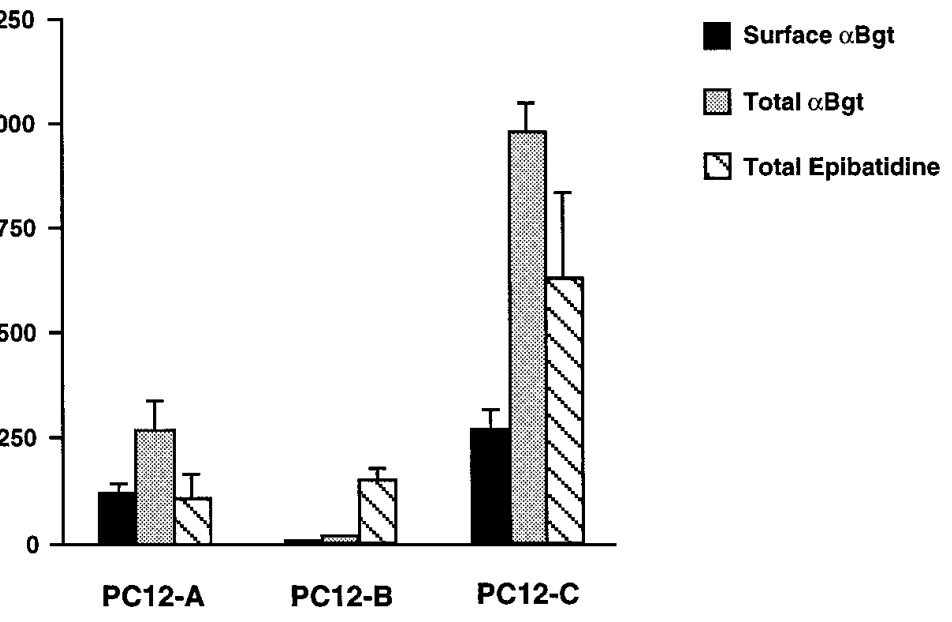

deletion of 10-20 nucleotides should have been apparent. The RNase protections (covering positions 913-1314), the PCR analysis, and the Northern blots found no defects in the $\alpha 7$ mRNA from PC12-B cells.

\section{Presence of $\alpha 7$ protein in PC12 AChRs}

In view of the transcript analysis, it became important to confirm that PC12 receptors capable of binding $\alpha \mathrm{Bgt}$ actually contain $\alpha 7$ subunits. This was demonstrated by using $\alpha$ Bgt-Actigel to affinity purify the receptors from PC12 cell extracts and then analyzing the eluted protein on immunoblots. The blots were probed with the anti- $\alpha 7 \mathrm{mAb}$ A7-1 generated against a fusion protein corresponding to the large putative cytoplasmic loop of the rat $\alpha 7$ gene product. A single component of $\sim 60 \mathrm{kDa}$ was recognized by the $\mathrm{mAb}$ in extracts from PC12-C cells (Fig. 6A). It was comparable in size to the monomeric $\alpha 7$ species obtained from chick brain and ciliary ganglion (Schoepfer et al., 1990; Vernallis et al., 1993). Competition with $250 \mu \mathrm{M}$ nicotine during the affinity purification caused the complete loss of the PC12 component, confirming the specificity of the purification. No specific bands were detected in extracts prepared from PC12-B cells. The results demonstrate that the $\alpha$ Bgt-binding species in PC12 cells contains the $\alpha 7$ gene product.

Immunoblot analysis of immunopurified material was used to compare the total amounts of $\alpha 7$ protein in extracts prepared from PC12-B and -C cells. mAb 319 coupled to Actigel was used to immunoprecipitate $\alpha 7$ protein, whereas mAb A7-1 was used to detect it on the blots. Although $\alpha 7$ protein could be detected in both cases, PC12-C cells contained much more of it than did 


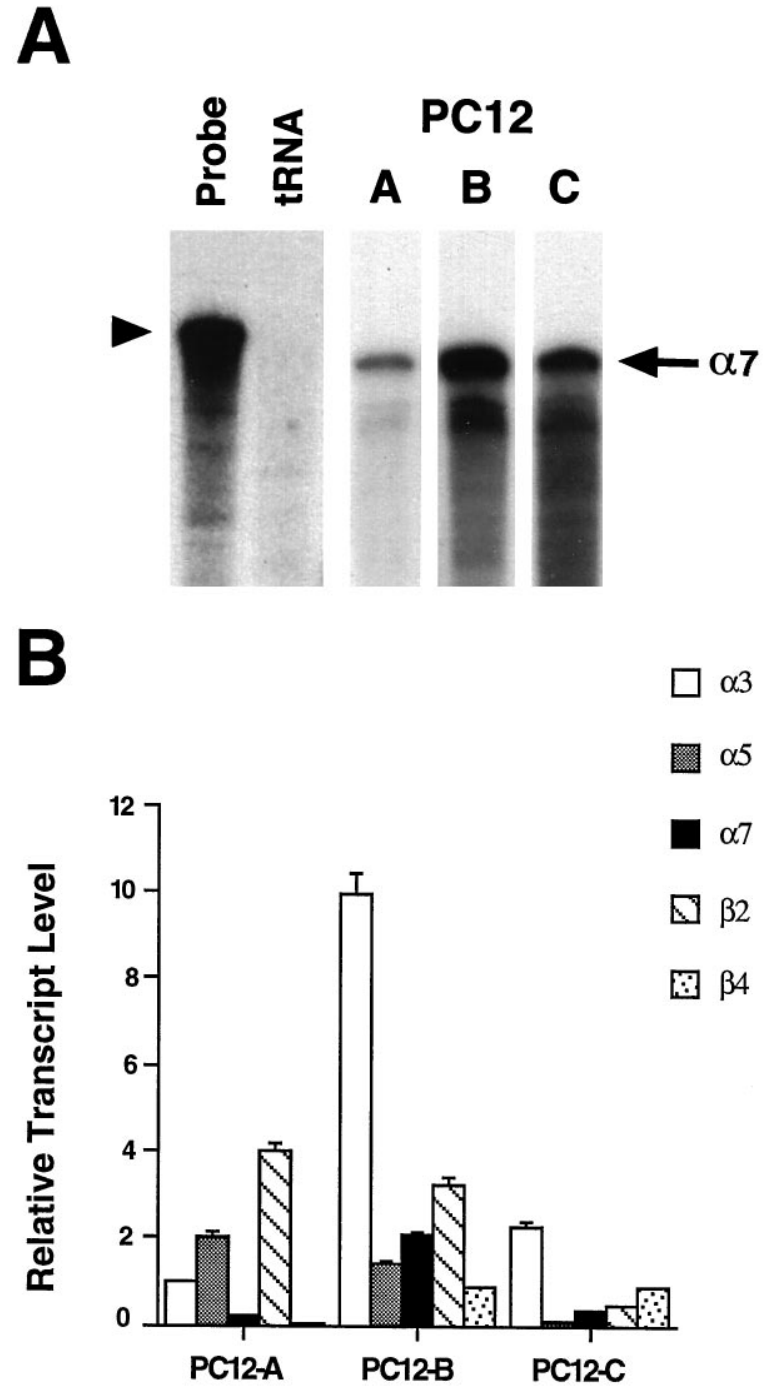

Figure 3. Relative amounts of AChR gene transcripts in three PC12 populations. RNase protection assays were used to measure the levels of $\alpha 3, \alpha 5, \alpha 7, \beta 2$, and $\beta 4$ transcripts in PC12-A-PC12-C cells. $A$, Representative RNase protection autoradiogram in which $20 \mu \mathrm{g}$ samples of total RNA were hybridized with a ${ }^{32} \mathrm{P}$-labeled $\alpha 7$ riboprobe (Probe lane, arrowhead). tRNA (15 $\mu \mathrm{g})$ served as a negative control; neither it nor probe alone protected a radiolabeled species (tRNA lane). Each PC12 RNA sample protected an $\alpha 7$ band of the expected size (arrow); the levels of $\alpha 7$ mRNA varied among the three cell populations, with the PC12-B cells expressing the most. $B$, The protected species obtained with each of the five probes was quantified on a Bio-Rad Molecular Imager. The results represent the mean \pm SEM for three to seven determinations from a total of three or four RNA preparations and are normalized to the signal obtained for $\alpha 3$ transcript in PC12-A cells.

PC12-B cells (Fig. $6 B$ ). The size of the monomeric $\alpha 7$ protein in PC12-B and -C cells is the same, consistent with the PCR and Northern analyses finding no differences in transcript size.

\section{Expression of AChRs from transfected genes}

The small amounts of $\alpha 7$ protein in PC12-B cells suggested that the transcript was competent but that a posttranslational block prevented assembly of the subunits and permitted rapid turnover. The possibility of a posttranslational block was tested by transfecting cells with chicken AChR gene constructs and then assaying cell extracts for receptor expression. Because the anti- $\alpha 7 \mathrm{mAb}$ 318 is specific for chicken, it enabled the transfected $\alpha 7$ gene

\section{PC12: B C}

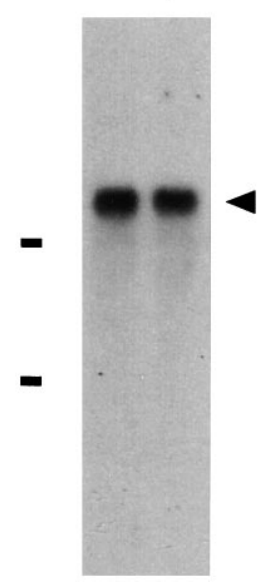

Figure 4. Northern blot analysis demonstrating $\alpha 7$ transcripts of equivalent size in PC12-B and PC12-C cells. Total RNA was isolated from each population and subjected to electrophoresis on a formaldehyde-agarose gel followed by capillary blotting onto a nylon membrane. The blot was hybridized with random-primed, ${ }^{32} \mathrm{P}$-labeled probe directed to the cytoplasmic domain of $\alpha 7$. Bars indicate the 28 and $18 \mathrm{~S}$ ribosomal RNAs. Both populations express a single $\alpha 7$ transcript $\sim 6.4 \mathrm{~kb}$ in length (arrowhead). The results are qualitative with respect to band intensity and should not be used to assess relative abundance of the transcripts. Similar results were obtained in four other experiments.

product to be distinguished from the endogenous rat homolog in solid-phase RIAs. The relative amounts of $\alpha$ Bgt binding in such assays in which only the chick $\alpha 7$ gene product was measured indicated that PC12-B cells are two orders of magnitude less efficient than $\mathrm{PC12}-\mathrm{C}$ cells at producing $\mathrm{AChRs}$ from a competent $\alpha 7$ cDNA construct (Fig. 7A).

For comparison, cells were also transfected with the chicken $\alpha 4$ and $\beta 2$ genes and assayed by RIA using the anti- $\alpha 4 \mathrm{mAb} 289$ to immunotether receptors and ${ }^{3} \mathrm{H}$-epibatidine to quantify them. In contrast to the results with the $\alpha 7$ construct, PC12-B cells were only a few-fold less efficient than PC12-C cells at producing transfected $\alpha 4 / \beta 2$ AChRs (Fig. 7A). A comparison was also performed using an $\alpha 7 / 5-\mathrm{HT}_{3}$ chimeric receptor gene construct in which the 5 '-terminal portion of the $5-\mathrm{HT}_{3}$ receptor gene encoding the $\mathrm{N}$-terminal putative extracellular portion of the protein was replaced with the equivalent region of the $\alpha 7$ gene. The encoded protein retains the ability to bind $\alpha \mathrm{Bgt}$ (Elsele et al., 1993). The construct was also engineered to encode a myc epitope on the $\mathrm{C}$ terminus so that the anti-myc mAb 9E10 could be used to immunotether the chimeric receptor in RIAs. Again, PC12-B cells were only a few-fold less efficient than PC12-C cells at expressing the transfected chimeric receptors (Fig. 7A).

A different way of analyzing the data is to calculate the ratio of different receptor types produced by transfected PC12-B cells and then to compare the ratio with that obtained from transfected PC12-C cells. This provides a way of normalizing results among experiments and reduces the inherent variation among transfections. Viewing the results in this way indicates that PC12-B cells are 10 - to 20 -fold less able to produce receptors from the transfected $\alpha 7$ construct than they are from either the transfected $\alpha 4$ and $\beta 2$ constructs or from the transfected $\alpha 7 / 5-\mathrm{HT}_{3}$ chimeric receptor construct compared with PC12-C cells (Fig. $7 B$ ). If all of the differences between PC12-B and -C cells in expressing either $\alpha 4 / \beta 2$ receptors or $\alpha 7 / 5-\mathrm{HT}_{3}$ receptors were considered nonspecific, e.g., attributed to differences in the efficiency of transfection, 
A

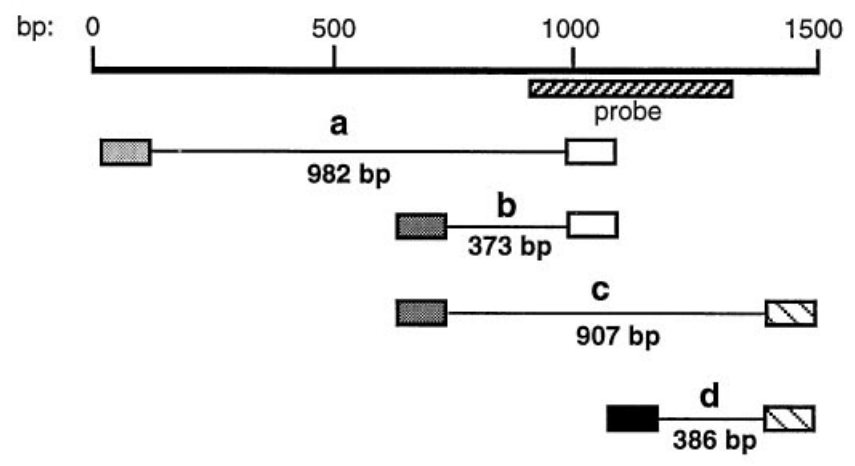

B

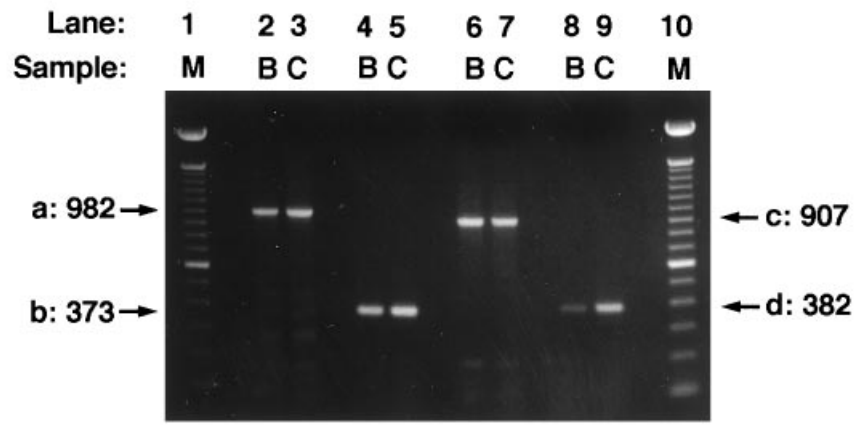

Figure 5. RT-PCR analysis comparing the coding regions of $\alpha 7$ mRNA from PC12-B and -C cells. $A$, Schematic showing the $\alpha 7$ transcript nucleotide sequence (heavy line) with the start coinciding with the A of the AUG start codon (Seguela et al., 1993). The expected PCR fragments (thin lines) were $a$ (982 bp), $b$ (373 bp), $c$ (907 bp), and $d$ (386 bp). Primer locations corresponded to nucleotide positions 18-38 (lightly stippled box), 627-646 (heavily stippled box), 981-1000 (open box), 1148-1167 (solid box), and 1516-1534 (hatched box). The sequence encoded by the RNase protection probe is indicated by the hatched bar. B, Agarose gels showing the amplified PCR fragments. First-strand cDNA was synthesized using reverse transcriptase and total RNA isolated from PC12-B and -C cells as templates. PCR was performed with the indicated sets of primers. Aliquots of the PCR reactions were run on $1.1 \%$ agarose gels, which were stained with ethidium bromide and photographed using a Polaroid camera. Lanes 1 and 10, M, Molecular weight standards (100 bp ladder from Gibco-BRL); lanes 2 and 3, PCR fragment a; lanes 4 and 5, fragment b; lanes 6 and 7 , fragment c; lanes 8 and 9 , fragment d. B, PC12-B RNA as template; $C$, PC12-C RNA as template. No differences were detected in the fragments amplified from the PC12-B and -C RNA, and in each case the fragment had the full size expected. Similar results were obtained when PCR was performed on cDNA synthesized from two independent RNA preparations.

the results would still demonstrate a substantial difference between the two cell populations in their ability to produce AChRs with $\alpha 7$ subunits. It is at least as likely, however, that all of the differences arise from the PC12-B defect, and that it is most severe in the case of the $\alpha 7$ gene product.

\section{Tests for cyclophilin involvement}

The possibility was considered that the PC12-B deficiency resulted from an altered or lost cyclophilin, because a cyclophilin has been shown to be necessary in Xenopus oocytes for expression of functional AChRs from the $\alpha 7$ gene (Helekar et al., 1994).
This was not a strong likelihood in the present case, however, because PC12-B cells show little deficit in expressing the $\alpha 7 / 5$ $\mathrm{HT}_{3}$ chimeric receptors, whereas Xenopus oocytes are as dependent on cyclophilin for $5-\mathrm{HT}_{3}$ receptors as they are for receptors composed of $\alpha 7$ subunits (Helekar et al., 1994).

A requirement for cyclophilin was tested in the present experiments by exposing PC12-C cells for $24 \mathrm{hr}$ to cyclosporin A, which inhibits cyclophilin, and then assaying cell extracts to determine whether the cells had reduced levels of AChRs. Cyclosporin A at $10 \mu \mathrm{M}$ had no effect on the amounts of $\alpha$ Bgt-binding AChRs with $\alpha 7$ subunits, either as measured in cell extracts by RIA to assay total receptors or as measured in cell culture with intact cells to assay surface receptors selectively (Fig. 8). Similarly, cyclosporin A at $10 \mu \mathrm{M}$ had no effect on the number of AChRs binding epibatidine in RIAs $(127 \pm 4 \%$, mean \pm SEM; $n=3$ experiments) compared with untreated control cells. Higher concentrations of cyclosporin A $(30 \mu \mathrm{M})$ were toxic and caused substantial cell loss. Blockade of new receptor expression by incubating cells with $0.5 \mu \mathrm{g} / \mathrm{ml}$ tunicamycin (which blocks N-linked glycosylation and prevents receptor maturation) showed that most of the $\alpha \mathrm{Bgt}-$ binding receptors are lost during a $24 \mathrm{hr}$ period (Fig. 8). The tunicamycin-induced loss was apparent both in the total receptor population and in those confined to the cell surface, indicating an ongoing receptor turnover by the cells. If a cyclosporin A-sensitive cyclophilin were required in PC12 cells, as it is in Xenopus oocytes for assembly of AChRs composed of $\alpha 7$ subunits, then the cyclosporin A treatment of PC12-C cells should have produced a large $(90 \%)$ reduction in the amount of $\alpha \mathrm{Bgt}-$ binding receptors tethered by anti- $\alpha 7 \mathrm{mAbs}$ in the RIA. It should also have substantially reduced the number of $\alpha$ Bgt-binding receptors on the cell surface, given the ongoing turnover. As a result, it is unlikely that a lost or altered cyclophilin accounts for the posttranslational deficiency in receptor production by $\mathrm{PC12}-\mathrm{B}$ cells.

\section{DISCUSSION}

This report provides the first demonstration, to our knowledge, of ACh-evoked currents in PC12 cells that can be blocked by $\alpha$ Bgt. It resolves a long-standing puzzle in the field and shows that the currents can vary dramatically among different PC12 populations. The currents correlate well with the presence of $\alpha$ Bgt-binding AChRs on the cells, and the receptors contain $\alpha 7$ protein, but there is no correlation between receptor levels and the amount of $\alpha 7$ transcript in the cells. Instead, receptor expression is shown to depend on a posttranslational event that is absent in some PC12 populations. The posttranslational event seems to be most critical for expression of AChRs containing $\alpha 7$ subunits, although it may influence less severely the expression of other ligand-gated ion channels as well.

Like their counterparts on rat hippocampal neurons and chick ciliary ganglion neurons (Zorumski et al., 1992; Alkondon and Albuquerque, 1993; Alkondon et al., 1994; Zhang et al., 1994), $\alpha$ Bgt-sensitive AChRs on PC12 cells seem to activate and desensitize rapidly. The quick desensitization of the receptors and their variable numbers among PC12 cell populations may explain why previous attempts failed to identify a current associated with the receptors. Another contributing factor is likely to have been the large $\alpha$ Bgt-resistant $\mathrm{ACh}$ responses that may often obscure the $\alpha$ Bgt-sensitive component. No antagonists have yet been identified that selectively block the $\alpha$ Bgt-resistant receptors.

The deficiency of PC12-B cells in producing functional $\alpha \mathrm{Bgt}-$ binding AChRs cannot be ascribed to a defect in their $\alpha 7$ tran- 
A

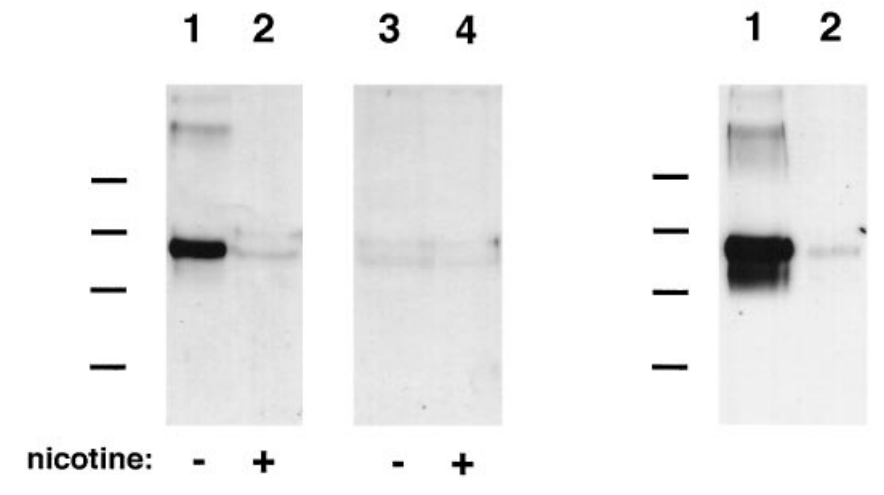

Figure 6. Immunoblot analysis showing $\alpha 7$ protein in PC12 AChRs. $A$, AChRs that bind $\alpha$ Bgt were affinity-purified from PC12-B and - $\mathrm{C}$ cell extracts by adsorption to $\alpha \mathrm{Bgt}$ coupled to Actigel beads. The adsorbed material was eluted and analyzed by immunoblots probed with the anti- $\alpha 7$ $\mathrm{mAb}$ A7-1 and visualized using a horseradish peroxidase-coupled secondary antibody followed by enhanced chemiluminescence. A single species of about $60 \mathrm{kDa}$ was obtained from PC12-C samples (lane 1). Nicotine at $250 \mu \mathrm{M}$ (lane 2) blocked adsorption of the component to the $\alpha$ Bgt-Actigel, indicating the specificity of the affinity purification. No components were obtained specifically when PC12-B cell extracts were analyzed by similar methods (lanes 3 and 4 ). Molecular weight standards (Bio-Rad) are as follows: phosphorylase B, $97 \mathrm{kDa}$; serum albumin, 66 $\mathrm{kDa}$; ovalbumin, $45 \mathrm{kDa}$; and carbonic anhydrase, $31 \mathrm{kDa}$. Similar results were obtained in a second experiment using $\mathrm{mAb} A 7-1$ as probe and in two experiments using mAb 319 as probe. $B$, Total $\alpha 7$ protein from PC12-B and -C cell extracts was analyzed by immunoprecipitating protein with the $\alpha 7$-specific mAb 319 coupled to Actigel and probing immunoblots of the purified material with mAb A7-1. A species of $60 \mathrm{kDa}$ component was obtained from both PC12-C (lane 1) and PC12-B (lane 2) cell extracts, although the latter contained much less of the component. Similar results were obtained in a second experiment. The band was absent when rat IgG-Actigel was substituted for the mAb 319-Actigel as a negative control (data not shown).

scripts and, therefore, differs from that found previously in a PC12 variant (Fanger et al., 1995). PC12-B cells have more $\alpha 7$ mRNA than do PC12-C cells, which make the receptors, and the transcripts are indistinguishable by Northern blot analysis, RNase protections, and RT-PCR analysis over the regions examined. Moreover, $\alpha 7$ protein is present in PC12-B cells and has the same size and antigenicity with respect to mAbs 319 and A7-1 as does $\alpha 7$ protein in PC12-C. The PC12-B transcript, therefore, seems competent to generate full-length in-frame $\alpha 7$ protein. The results indicate that a posttranscriptional deficiency is most likely to account for the limitations of PC12-B cells in producing functional AChRs with $\alpha 7$ subunits.

Heterologous expression of the $\alpha 7$ gene alone in either Xenopus oocytes or stably transfected cell lines is sufficient to generate functional AChRs that are blocked by $\alpha$ Bgt (Couturier et al., 1990; Seguela et al., 1993; Puchacz et al., 1994; Gopalakrishnan et al., 1995; Quik et al., 1996). The inability of PC12-B cells to do so despite their having what seems to be competent $\alpha 7$ mRNA, therefore, implies a posttranslational block. Strong evidence of such a block was provided by the transfection experiments showing that PC12-B cells are two orders of magnitude less efficient at producing $\alpha$ Bgt-binding AChRs from an $\alpha 7$ gene construct than are PC12-C cells. Differences of only a few-fold were observed between PC12-B and -C cells when comparing their abilities to make receptors containing the $\alpha 4$ and $\beta 2$ subunits or chimeric $\alpha 7 / 5-\mathrm{HT}_{3}$ receptor subunits from transfected gene constructs.
These small differences may reflect differences in the efficiency of transfection between PC12-B and -C cells. Alternatively, the posttranslational defect restricting receptor production in PC12-B cells applies to many kinds of ligand-gated ion channels but is most stringent for receptors containing $\alpha 7$ protein.

What is the nature of the posttranslational block? It cannot be ascribed to differences in growth medium and is not overcome by NGF. One possibility is that the block is confined to AChRs containing $\alpha 7$ subunits and reflects a requirement for other kinds of subunits to be co-assembled in the receptors. Failure of $\alpha 7$ subunits to bind appropriate partners for co-assembly could result in rapid turnover of the protein and account for the low levels present in PC12-B cells. Although heterologous expression of the $\alpha 7$ subunit alone can produce functional $\alpha \mathrm{Bgt}$-sensitive AChRs, as cited above, it is difficult to exclude the possibility that the usually limited amounts of functional receptor obtained in such cases are made possible by small amounts of other required AChR gene products being expressed at low levels by the host cell. Immunological analysis of native AChRs containing $\alpha 7$ subunits in chick ciliary ganglion neurons, for example, has indicated that the receptors lack all of the known AChR gene products expressed by chick neurons (Vernallis et al., 1993), but it remains possible that other $\mathrm{AChR}$ genes remain to be identified.

A different possibility is that the posttranslational block reflects loss of a specific component(s) required for efficient assembly or stabilization of certain classes of ligand-gated ion channels. The defect in PC12-B cells is not global in its effects, because the cells can express other kinds of receptors from both transfected and endogenous genes. The latter include AChRs capable of binding epibatidine and generating $\alpha \mathrm{Bgt}$-resistant $\mathrm{ACh}$ responses. The fact that PC12-B cells, however, generally have higher levels of all AChR transcripts tested (with the exception of $\beta 4$ ) and yet lower levels of epibatidine binding than do PC12-C cells suggests that the PC12-B defect may extend in a mild form to other kinds of ligand-gated ion channels. The post-translational defect described here is different from that preventing expression of NMDA receptors in PC12 cells. Although the cells synthesize NMDAR1 mRNA, they do not produce functional NMDA receptors and have little NMDAR1 protein until transfected with an NMDAR1 cDNA construct (Sucher et al., 1993). The simplest interpretation is that the endogenous NMDAR1 transcripts do not permit significant translation, perhaps because of interference from their untranslated regions (Sucher et al., 1993).

Precedent for different requirements in receptor assembly comes from studies on heterologous expression of AChR genes in Xenopus oocytes. Production of functional homomeric, but not heteromeric, AChRs containing $\alpha 7$ protein is blocked by cyclosporin A through its inhibition of cyclophilin (Helekar et al., 1994). A lost or defective cyclophilin is unlikely to account for the deficiency detected here in PC12-B cells, because cyclosporin A treatment did not prevent receptor production in PC12-C cells. In addition, PC12-B cells are nearly as efficient as PC12-C cells in expressing an $\alpha 7 / 5-\mathrm{HT}_{3}$ chimeric receptor, whereas expression of $5-\mathrm{HT}_{3}$ receptors in Xenopus oocytes mimics that of receptors containing $\alpha 7$ subunits in requiring a cyclophilin (Helekar et al., 1994).

The inability of PC12-A cells to produce $\alpha \mathrm{Bgt}$-insensitive ACh responses deserves comment. Some epibatidine binding was detected in the cell extracts indicating the existence of AChRs. Possibly the receptors were sequestered in an intracellular pool and therefore unable to generate responses. The low levels of $\beta 4$ 

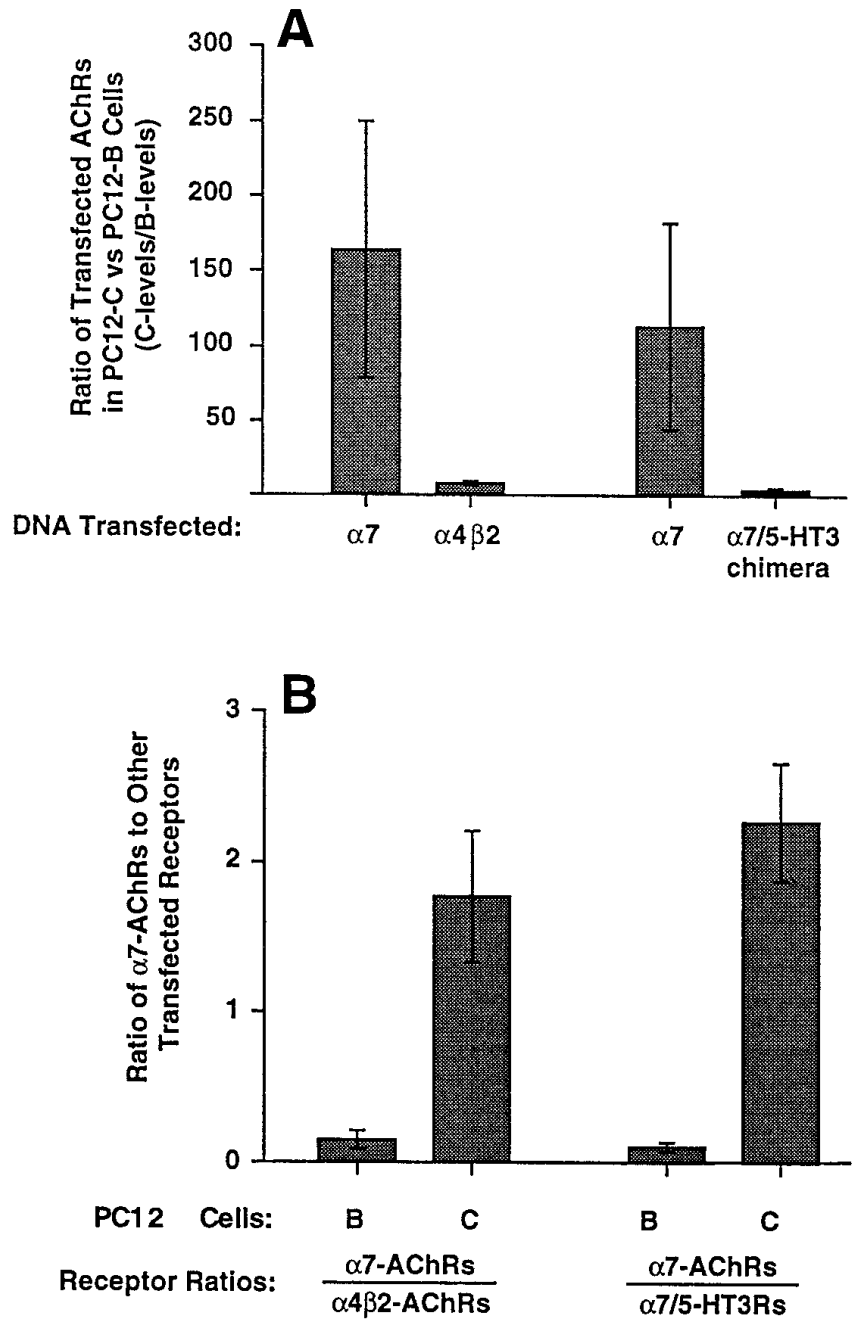

Figure 7. Expression of transfected receptor gene constructs in $\mathrm{PC} 12$ cells. PC12-B and -C cells were transfected with chicken AChR cDNA constructs encoding either the $\alpha 7$ or the $\alpha 4$ and $\beta 2$ subunits or, in separate experiments, containing either the $\alpha 7$ or the $\alpha 7 / 5-\mathrm{HT}_{3}$ chimeric receptor subunit. Cell extracts were prepared $20-48 \mathrm{hr}$ later and assayed by RIA for ${ }^{125} \mathrm{I}-\alpha \mathrm{Bgt}$ binding to receptors tethered either by anti- $\alpha 7 \mathrm{mAb} 318$, which recognizes chick but not rat $\alpha 7$ protein, or by anti-myc mAb 9E10, which recognizes the epitope-tagged $\alpha 7 / 5-\mathrm{HT}_{3}$ receptor protein and by RIA for ${ }^{3} \mathrm{H}$-epibatidine binding to receptors tethered with anti- $\alpha 4 \mathrm{mAb}$ 289 , which recognizes chick but not rat $\alpha 4$ protein. The selectivities of the antibodies required that the receptors contain one or more transfected gene products to be assayed (receptors containing only endogenous gene components would not have been retained). $A$, Ratio of receptor levels in PC12-C cell extracts divided by that in PC12-B cell extracts obtained from the same experiment. Values represent the mean \pm SEM of three or four experiments. Absolute levels of $\alpha \mathrm{Bgt}$ binding to chick AChRs with $\alpha 7$ subunits in transfected PC12-B and PC12-C cells averaged 6 and 498 fmol/culture, respectively, for the experiments with $\alpha 4 \beta 2$ and 4 and 258 fmol/culture, respectively, for the experiments with $\alpha 7 / 5-\mathrm{HT}_{3}$. Levels of epibatidine binding for PC12-B and PC12-C cells were 43 and $288 \mathrm{fmol} /$ culture, respectively, in the $\alpha 4 \beta 2$ experiments; levels of $\alpha \mathrm{Bgt}$ binding to $5-\mathrm{HT}_{3}$ chimeras were 37 and $111 \mathrm{fmol} /$ culture, respectively. PC12-B cells have a large deficiency in the expression of AChRs with $\alpha 7$ subunits compared with PC12-C cells. $B$, Relative number of $\alpha$ Bgt-binding AChRs produced by transfected PC12-B $(B)$ or PC12-C $(C)$ cells with chick $\alpha 7$ subunits $(\alpha 7-A C h R s)$ divided by either the number of receptors with $\alpha 4$ and $\beta 2$ subunits $(\alpha 4 \beta 2-A C h R s)$ or $\alpha 7 / 5-\mathrm{HT}_{3}$ chimeric receptor subunits $(\alpha 7 / 5-H T 3 R s)$. PC12-B cells are significantly more impaired at expressing $\alpha$ Bgt-binding AChRs from the $\alpha 7$ construct than they are at expressing either AChRs from the $\alpha 4$ and $\beta 2$ constructs $(p<0.03$ by Student's unpaired $t$ test) or receptors from the $\alpha 7 / 5-\mathrm{HT}_{3}$ chimeric construct ( $p<$ $0.002)$.

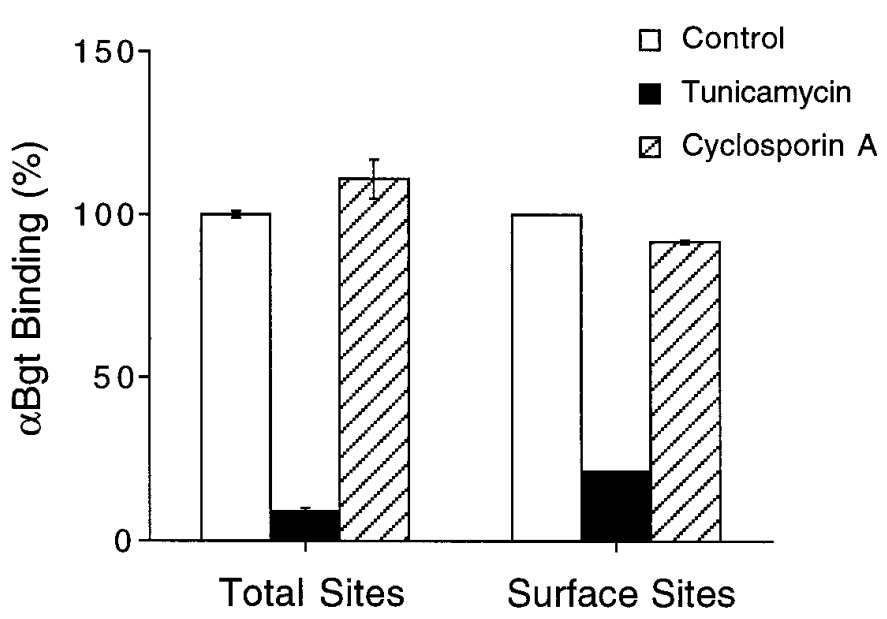

Figure 8. Lack of cyclosporin A effects on levels of PC12 receptors binding $\alpha \mathrm{Bgt}$. PC12-C cells in culture were treated either with vehicle (Control), tunicamycin $(1 \mu \mathrm{g} / \mathrm{ml})$, or cyclosporin A $(10 \mu \mathrm{M})$ for $24 \mathrm{hr}$ and then assayed either for $\alpha$ Bgt binding in RIAs with mAb 318 (which recognizes the chick but not rat $\alpha 7$ gene product) to immunotether receptors (Total Sites) or for $\alpha$ Bgt-binding to intact cells in culture (Surface Sites). Values represent the mean \pm SEM of three or four separate experiments and are expressed as percentages of those obtained from control cells. Tunicamycin treatment caused a large reduction in $\alpha$ Bgt binding, indicating that receptors both on the cell surface and inside were normally turning over. Cyclosporin A treatment had little effect either on the total number of $\alpha \mathrm{Bgt}$-binding receptors assayed or on those present on the cell surface.

transcript in PC12-A cells may have limited the ability of the cells to produce receptors targeted for the cell surface. It remains unclear, however, why the $\alpha 3$ and $\beta 2$ gene products expressed by the cells were not alone sufficient to generate functional $\alpha \mathrm{Bgt}$ resistant AChRs as they do in Xenopus oocytes (Boulter et al., 1987; Deneris et al., 1988; Gross et al., 1991).

PC12 cells passaged many times in culture under different conditions might well generate diverse variants. What is interesting about the present variations is the possibility that they reflect differences in the machinery cells use to assemble and maintain certain classes of membrane proteins. Ligand-gated ion channels are multimeric proteins containing both hydrophobic and hydrophilic transmembrane domains constituting the channel. They pose considerable challenges from a structural biological point of view in terms of proper assembly and insertion into the cell membrane. Neurons must efficiently produce large numbers of such channel proteins while avoiding potentially lethal errors such as creating spontaneously active channels or ones that permit excessive calcium to enter the cell. A gain-of-function mutation in a Caenorhabditis elegans gene homologous to $\alpha 7$ illustrates the potential danger of producing inappropriate receptors; the mutation causes cell death (Treinin and Chalfie, 1995). Quality control may come in the form of special chaperones that guide the assembly process and help prevent or discard errors.

\section{REFERENCES}

Alkondon M, Albuquerque EX (1993) Diversity of nicotinic acetylcholine receptors in rat hippocampal neurons. I. Pharmacological and functional evidence for distinct structural subtypes. J Pharmacol Exp Ther 265:1455-1473.

Alkondon M, Reinhardt S, Lobron C, Hermsen B, Maelicke A, Albuquerque EX (1994) Diversity of nicotinic acetylcholine receptors in rat hippocampal neurons. II. The rundown and inward rectification of agonist-elicited whole-cell currents and identification of receptor subunits by in situ hybridization. J Pharmacol Exp Ther 271:494-506. 
Amy CM, Bennett EL (1983) Increased sodium ion conductance through nicotinic acetylcholine receptor channels in PC12 cells exposed to nerve growth factors. J Neurosci 3:1547-1553.

Anand R, Peng X, Lindstrom J (1993) Homomeric and native $\alpha 7$ acetylcholine receptors exhibit remarkably similar but non-identical pharmacological properties, suggesting that the native receptor is a heteromeric protein complex. FEBS Lett 327:241-246.

Bertrand D, Galzi JL, Devillers-Thiery A, Bertrand S, Changeux JP (1993) Mutations at two distinct sites within the channel domain M2 alter calcium permeability of neuronal $\alpha 7$ nicotinic receptor. Proc Natl Acad Sci USA 90:6971-6975.

Boulter J, Evans K, Goldman D, Martin G, Treco D, Heinemann S, Patrick J (1986) Isolation of a cDNA clone coding for a possible neural nicotinic acetylcholine receptor $\alpha$-subunit. Nature 319:368-374.

Boulter J, Connolly J, Deneris E, Goldman D, Heinemann S, Patrick J (1987) Functional expression of two neuronal nicotinic acetylcholine receptors from cDNA clones identifies a gene family. Proc Natl Acad Sci USA 84:7763-7767.

Boulter J, O'Shea-Greenfield A, Duvoisin RM, Connolly JG, Wada E, Jensen A, Gardner PD, Ballivet M, Deneris ES, McKinnon D, Heinemann S, Patrick J (1990) $\alpha 3, \alpha 5$, and $\beta 4$ : three members of the rat neuronal nicotinic acetylcholine receptor-related gene family form a gene cluster. J Biol Chem 265:4472-4482.

Chan J, Quik M (1993) A role for the nicotinic $\alpha$-bungarotoxin receptor in neurite outgrowth in PC12 cells. Neuroscience 56:441-451.

Chomczynski P, Sacchi N (1987) Single-step method of RNA isolation by acid guanidinium thiocyanate-phenol-chloroform extraction. Anal Biochem 162:156-159.

Conroy WG, Berg DK (1995) Neurons can maintain multiple classes of nicotinic acetylcholine receptors distinguished by different subunit compositions. J Biol Chem 270:4424-4431.

Corriveau RA, Berg DK (1993) Coexpression of multiple acetylcholine receptor genes in neurons: quantification of transcripts during development. J Neurosci 13:2662-2671.

Corriveau RA, Romano SJ, Conroy WG, Oliva L, Berg DK (1995) Expression of neuronal acetylcholine receptor genes in vertebrate skeletal muscle during development. J Neurosci 15:1372-1383.

Couturier S, Bertrand D, Matter J-M, Hernandez M-C, Bertrand S, Millar N, Valera S, Barkas T, Ballivet M (1990) A neuronal nicotinic acetylcholine receptor subunit $(\alpha 7)$ is developmentally regulated and forms a homo-oligomeric channel blocked by $\alpha$-Btx. Neuron 5:847-856.

Daly JW, Nishizawa Y, Edwards M, Waters JA, Aronstam RS (1991) Nicotinic receptor-elicited sodium flux in rat pheochromocytoma PC12 cells: effects of agonists, antagonists, and noncompetitive blockers. Neurochem Res 16:489-500.

Del Toro ED, Juiz JM, Peng X, Lindstrom J, Criado M (1994) Immunocytochemical localization of the $\alpha 7$ subunit of the nicotinic acetylcholine receptor in the rat central nervous system. J Comp Neurol 349:325-342.

Deneris ES, Connolly J, Boulter J, Wada E, Wada K, Swanson LW, Patrick J, Heinemann S (1988) Primary structure and expression of $\beta 2$ : a novel subunit of neuronal nicotinic acetylcholine receptors. Neuron 1:45-54.

Dichter MA, Tischler AS, Greene LA (1977) Nerve growth factor induced increase in electrical excitability and acetylcholine sensitivity of a rat pheochromocytoma cell line. Nature 268:501-504.

Elsele J-L, Bertrand S, Galzi J-L, Devillers-Thiery A, Changeux J-P, Bertrand D (1993) Chimaeric nicotinic-serotonergic receptor combines distinct ligand binding and channel specificities. Nature 366:479-483.

Fanger GR, Brennan C, Henderson LP, Gardner PD, Maue RA (1995) Differential expression of sodium channels and nicotinic acetylcholine receptor channels in nnr variants of the PC12 pheochromocytoma cell line. J Membr Biol 144:71-80.

Freedman R, Coon H, Myles-Worsley M, Orr-Urtreger A, Olincy A, Davis A, Polymeropoulos M, Holik J, Hopkins J, Hoff M, Rosenthal J, Waldo MC, Reimherr F, Wender P, Yaw J, Young DA, Breese CR, Adams C, Patterson D, Adler LE, Kruglyak L, Leonard S, Byerly W (1997) Linkage of a neurophysiological deficit in schizophrenia to chromosome 15 locus. Proc Natl Acad Sci USA 94:587-592.

Garcia-Guzman M, Sala F, Sala S, Campos-Caro A, Stuhmer W, Gutierrez LM, Criado M (1995) $\alpha$-Bungarotoxin-sensitive nicotinic receptors on bovine chromaffin cells: molecular cloning, functional expression, and alternative splicing of the $\alpha 7$ subunit. Eur $\mathrm{J}$ Neurosci 7:647-655.
Gerzanich V, Peng X, Wang F, Wells G, Anand R, Fletcher S, Lindstrom J (1995) Comparative pharmacology of epibatidine: a potent agonist for neuronal nicotinic acetylcholine receptors. Mol Pharmacol 48:774-782.

Gopalakrishnan M, Buisson B, Touma E, Giordano T, Campbell JE, Hu IC, Donnelly-Roberts D, Arneric SP, Bertrand D, Sullivan JP (1995) Stable expression and pharmacological properties of the human $\alpha 7$ nicotinic acetylcholine receptor. Eur J Pharmacol 290:237-246.

Gotti C, Hanke W, Maury K, Moretti M, Ballivet M, Clementi F, Bertrand D (1994) Pharmacology and biophysical properties of $\alpha 7$ and $\alpha 7-\alpha 8 \alpha$-bungarotoxin receptor subtypes inmmunopurified from the chick optic lobe. Eur J Neurosci 6:1281-1292.

Gray R, Rajan AS, Radcliffe KA, Yakehiro M, Dani JA (1996) Hippocampal synaptic transmission enhanced by low concentrations of nicotine. Nature 383:713-716.

Greene LA, Tischler AS (1976) Establishment of a noradrenergic clonal line of rat adrenal pheochromocytoma cells which respond to nerve growth factor. Proc Natl Acad Sci USA 73:2424-2428.

Gross A, Ballivet M, Rungger D, Bertrand D (1991) Neuronal nicotinic acetylcholine receptors expressed in Xenopus oocytes: role of the $\alpha$ subunit in agonist sensitivity and desensitization. Eur $\mathbf{J}$ Physiol 419:545-551.

Gurantz D, Margiotta JF, Harootunian AT, Dionne VE (1993) Modulation by albumin of neuronal cholinergic sensitivity. Mol Pharmacol 43:807-812.

Halvorsen SW, Berg DK (1989) Specific down-regulation of the $\alpha$-bungarotoxin binding component on chick autonomic neurons by ciliary neuronotrophic factor. J Neurosci 9:3673-3680.

Hamill OP, Marty A, Neher E, Sakmann B, Sigworth FJ (1981) Improved patch-clamp techniques for high-resolution current recordings from cells and cell-free membrane patches. Pflügers Arch 391:85-100.

Helekar SA, Char D, Neff S, Patrick J (1994) Prolyl isomerase requirement for the expression of functional homo-oligomeric ligand-gated ion channels. Neuron 12:179-189.

Henderson LP, Gdovin MJ, Liu CL, Gardner PD, Maue RA (1994) Nerve growth factor increases the nicotinic ACh receptor gene expression and current density in wild-type and protein kinase A-deficient PC12 cells. J Neurosci 14:1153-1163.

Herlitze S, Koenen M (1990) A general and rapid mutagenesis method using polymerase chain reaction. Gene 91:143-147.

Kemp G, Edge M (1987) Cholinergic function and $\alpha$-bungarotoxin binding in PC12 cells. Mol Pharmacol 32:356-363.

Keyser KT, Britto LRG, Schoepfer R, Whiting P, Cooper J, Conroy W, Brozozowska-Prechtl A, Karten HJ, Lindstrom J (1993) Three subtypes of $\alpha$-bungarotoxin-sensitive nicotinic acetylcholine receptors are expressed in chick retina. J Neurosci 13:442-454.

Listerud M, Brussaard AB, Devay P, Colman DR, Role LW (1991) Functional contribution of neuronal $\mathrm{nAChR}$ subunits revealed by antisense oligonucleotides. Science 254:1518-1521.

Mandel G, Cooperman SS, Maue RA, Goodman RH, Brehm P (1988) Selective induction of brain type II $\mathrm{Na}^{+}$channels by nerve growth factor. Proc Natl Acad Sci USA 85:924-928.

Mandelzys A, Pie B, Deneris ES, Cooper E (1994) The developmental increase in $\mathrm{ACh}$ current densities on rat sympathetic neurons correlates with changes in nicotinic ACh receptor $\alpha$-subunit gene expression and occurs independent of innervation. J Neurosci 14:2357-2364.

McGehee D, Heath M, Gelber S, Role LW (1995) Nicotine enhancement of fast excitatory synaptic transmission in CNS by presynaptic receptors. Science 269:1692-1697.

Patrick J, Stallcup WG (1977a) Immunological distinction between acetylcholine receptor and the $\alpha$-bungarotoxin-binding component on sympathetic neurons. Proc Natl Acad Sci USA 74:4689-4692.

Patrick J, Stallcup WG (1977b) $\alpha$-Bungarotoxin binding and cholinergic receptor function on a rat sympathetic nerve line. $\mathrm{J}$ Biol Chem 252:8629-8633.

Puchacz E, Buisson B, Bertrand D, Lukas RJ (1994) Functional expression of nicotinic acetylcholine receptors containing rat $\alpha 7$ subunits in human SH-SY5Y neuroblastoma cells. FEBS Lett 354:155-159.

Pugh PC, Berg DK (1994) Neuronal acetylcholine receptors that bind $\alpha$-bungarotoxin mediate neurite retraction in a calcium-dependent manner. J Neurosci 14:889-896.

Quik M, Choremis J, Komourian J, Lukas RJ, Puchacz E (1996) Similarity between rat brain nicotinic $\alpha$-bungarotoxin receptors and stably expressed $\alpha$-bungarotoxin binding sites. J Neurochem 67:145-154.

Rogers SW, Gahring LC, Papke RL, Heinemann S (1991) Identification 
of cultured cells expressing ligand-gated cationic channels. Protein Expr Purif 2:108-116.

Rogers SW, Mandelzys A, Deneris ES, Cooper E, Heinemann S (1992) The expression of nicotinic acetylcholine receptors by PC12 cells treated with NGF. J Neurosci 12:4611-4623.

Role LW, Berg DK (1996) Nicotinic receptors in the development and modulation of CNS synapses. Neuron 16:1077-1085.

Sargent PB (1993) The diversity of neuronal nicotinic acetylcholine receptors. Annu Rev Neurosci 16:403-443.

Schoepfer R, Conroy WG, Whiting P, Gore M, Lindstrom J (1990) Brain $\alpha$-bungarotoxin binding protein cDNAs and mAbs reveal subtypes of this branch of the ligand-gated ion channel gene superfamily. Neuron 5:35-48.

Seguela P, Wadiche J, Dineley-Miller K, Dani JA, Patrick JW (1993) Molecular cloning, functional properties, and distribution of rat brain $\alpha 7$ : a nicotinic cation channel highly permeable to calcium. J Neurosci 13:596-604.

Sucher NJ, Brose N, Deitcher DL, Awobuluyi M, Gasic GP, Bading H, Cepko CL, Greenberg ME, Jahn R, Heinemann SF, Lipton SA (1993) Expression of endogenous NMDAR1 transcripts without receptor protein suggests post-transcriptional control in PC12 cells. J Biol Chem 268:22299-22304.

Toledo-Aral JJ, Brehm P, Halegoua S, Mandel G (1995) A single pulse of nerve growth factor triggers long-term neuronal excitability through sodium channel gene induction. Neuron 14:607-611.

Treinin M, Chalfie M (1995) A mutated acetylcholine receptor subunit causes neuronal degeneration in C. elegans. Neuron 14:871-877.
Vernallis AB, Conroy WG, Berg DK (1993) Neurons assemble acetylcholine receptors with as many as three kinds of subunits while maintaining subunit segregation among receptor subtypes. Neuron 10:451-464.

Vijayaraghavan S, Huang B, Blumenthal EM, Berg DK (1995) Arachidonic acid as a possible negative feedback inhibitor of nicotinic acetylcholine receptors on neurons. J Neurosci 15:3679-3687.

Whiting PJ, Schoepfer R, Conroy WG, Gore MJ, Keyser KT, Shimasaki S, Esch F, Lindstrom JM (1991a) Expression of nicotinic acetylcholine receptor subtypes in brain and retina. Mol Brain Res 10:61-70.

Whiting P, Schoepfer R, Lindstrom J, Priestley T (1991b) Structural and pharmacological characterization of the major brain nicotinic acetylcholine receptor subtype stably expressed in mouse fibroblasts. Mol Pharmacol 40:463-472.

Zhang Z-w, Berg DK (1995) Patch-clamp analysis of glycine-induced currents in chick ciliary ganglion neurons. J Physiol 487:395-405.

Zhang Z-w, Vijayaraghavan S, Berg DK (1994) Neuronal acetylcholine receptors that bind $\alpha$-bungarotoxin with high affinity function as ligandgated ion channels. Neuron 12:167-177.

Zhang Z-w, Coggan JS, Berg DK (1996) Synaptic currents generated by neuronal acetylcholine receptors sensitive to $\alpha$-bungarotoxin. Neuron 17:1231-1240.

Zorumski CF, Thio LL, Isenberg KE, Clifford DB (1992) Nicotinic acetylcholine currents in cultured postnatal rat hippocampal neurons. Mol Pharmacol 41:931-936. 